

\section{About ICIMOD}

The International Centre for Integrated Mountain Development (ICIMOD) is an independent 'Mountain Learning and Knowledge Centre' serving the eight countries of the

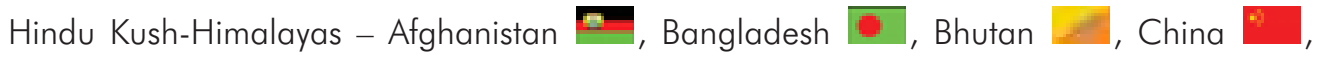
India community. Founded in 1983, ICIMOD is based in Kathmandu, Nepal, and brings together a partnership of regional member countries, partner institutions, and donors with a commitment for development action to secure a better future for the people and environment of the extended Himalayan region. ICIMOD's activities are supported by its core programme donors: the governments of Austria, Denmark, Germany, Netherlands, Norway, Switzerland, and its regional member countries, along with over thirty project co-financing donors. The primary objective of the Centre is to promote the development of an economically and environmentally sound mountain ecosystem and to improve the living standards of mountain populations. 


\title{
Community Rights and Livelihoods in the Nanda Devi Biosphere Reserve
}

\section{Sunil Dutt Kainthola'}

\author{
with \\ Dhan Singh Rana ${ }^{2}$, Nandan Singh ${ }^{3}$, \\ Pratibha Naithani ${ }^{4}$, Swagata Kainthola ${ }^{5}$, and \\ Bhupendra Singh Negi ${ }^{5}$
}

\footnotetext{
${ }^{1}$ Secretary, Janadhar and Convener, Alliance for Development, Dehra Dun, Uttaranchal, (dhaar@vsnl.com); ${ }^{2}$ Ex Gram Pradhan of Lata village; ${ }^{3}$ Yuvak Mangal Dal, Lata village; ${ }^{4}$ Department of Political Science, St. Xavier's College, Mumbai; ${ }^{5}$ Janadhar, Dehra Dun
}

International Centre for Integrated Mountain Development (ICIMOD) Kathmandu, Nepal 


\section{Copyright $\odot 2006$}

International Centre for Integrated Mountain Development (ICIMOD)

All rights reserved

\section{Published by the}

International Centre for Integrated Mountain Development

G.P.O. Box 3226

Kathmandu, Nepal

ISBN-10 92-9115-012-6

ISBN-13 978-92-9115-012-0

\section{Editorial Team}

Joyce M. Mendez (Editor)

A. Beatrice Murray (Senior Editor)

Dharma R. Maharjan (Technical Support and Layout Design)

Asha K. Thaku (Maps and Illustrations)

\section{Printed and bound in Nepal by \\ Hill Side Press (P) Ltd. ??? \\ Kathmandu}

\section{Reproduction}

This publication may be reproduced in whole or in part and in any form for educational or non-profit purposes without special permission from the copyright holder, provided acknowledgement of the source is made. ICIMOD would appreciate receiving a copy of any publication that uses this publication as a source.

No use of this publication may be made for resale or for any other commercial purpose whatsoever without prior permission in writing from ICIMOD.

\section{Note}

The views and interpretations in this publication are those of the author(s). They are not attributable to ICIMOD and do not imply the expression of any opinion concerning the legal status of any country, territory, city or area of its authorities, or concerning the delimitation of its frontiers or boundaries, or the endorsement of any product.

The affiliation and professional positions of the authors were those current at the time the study was conducted. 


\title{
preface
}

Conflicts over natural resources in the western Himalayas of India are not a recent phenomenon. While earlier conflicts often resulted from contention over natural resources, for example when the state in its bid to exploit timber was resisted by communities as illustrated by the Chipko movement, a more recent source of conflict is linked ironically with the laudable motive of conservation. What remains common is the continuing challenge of maintaining sources of livelihood for local communities while preserving the environment.

This publication describes the problems faced by and reactions of the communities of the Niti Valley in the Nanda Devi protected area, as an example of this type of conservation-related conflict. The aim is to provide a basis for discussion and to understand better the impacts of and reactions to conservation activities. The publication was developed from one of a series of case studies prepared under the 'Participatory Action Research Programme on Equity and Policy in the Management of Common Property Resources in the Hindu Kush-Himalayan Region' project which was funded by the Swiss Agency for Development Cooperation (SDC).

The Niti Valley came into international limelight as a result of the Chipko movement - when local communities resisted organised timber felling by the state - and became an exemplary story of a local initiative for conservation. Paradoxically, when the Nanda Devi area was notified as protected in 1982 to support conservation, these same communities lost much of their usage rights in their traditional commons. The price of conservation was mainly borne by the local communities, the same people who had raised awareness of the need for conservation, and this was mainly because of their inability to have their voices heard and valued in the proper quarters and to negotiate an equitable deal. Recent developments indicate a promising increase in awareness of the needs and role of the 'local guardians' of these natural resources, and the development of activities to redress the issues.

ICIMOD recognises equitable management of common property resources as a key in working towards sustainable development. Especially in mountain areas, where local communities depend intrinsically on natural resources, loss of usage rights can have dire consequences for a community and lead to structural changes in the traditional livelihood systems. It can also be self-defeating, as community management systems designed to ensure sustainable rather than destructive use of natural resources are destroyed, and uncontrolled 'illegal' use - as a matter of survival - becomes the norm. ICIMOD believes that a continuing dialogue amongst stakeholders is needed to address issues of equity and poverty for sustaining and conserving the natural resources of the Himalayan region. We hope that this publication will contribute to this dialogue.

\author{
Michael Kollmair \\ Programme Manager \\ Culture, Equity, Gender and Governance \\ ICIMOD
}




\section{acknowledgements}

We would like to thank ICIMOD and its Director General, Dr. J. Gabriel Campbell, for providing us with this unique opportunity to do a case study on the communities of the Niti Valley in the Nanda Devi protected area, and for enabling us to interact with people and organisations working on similar issues in the HKH region.

Special thanks to to Dr. Anupam Bhatia, then Programme Manager of the Culture, Equity, Gender and Governance (CEGG) Programme of ICIMOD, for being such a perfect host making us comfortable in these multilingual gatherings. Thanks also to Mr. Suman Rai, Coordinator of Equity and Poverty at CEGG, for visiting Lata village and offering us this privilege to undertake an action research project on the Nanda Devi Biosphere Reserve. The study has allowed us to understand better the importance of equity in the development process.

We also gratefully acknowledge the financial support provided by the Swiss Agency for Development Cooperation (SDC), which has allowed us to look into the impact of conservation and its restrictions on the communities around the Nanda Devi Biosphere Reserve and the communities' instinctive reactions to defend their own right to survival.

The authors also gratefully acknowledge Dr. R. K. Maikhuri for his kind permission to use tables and data from his various research undertakings; and Khila Bisht, Biju Negi, Rajiv Rawat, and Dr. Keith Bosak, for their valuable inputs in analysing and presenting the study's findings. We would also like to thank Ms. Radhika Gupta and Dr. Michael Kollmair of the present CEGG, for acknowledging the study's value and pushing for the publication of its findings; and the ICIMOD Information, Management Communication and Outreach Division (IMCO): Joyce M. Mendez and Dr. A. Beatrice Murray (Editors), Dharma R. Maharjan (layout design) and Asha Kaji Thaku (cover and other illustrations) for making this possible. Special thanks also to the people behind the Nanda Devi Campaign for giving us permission to use some of the photos of their recent activities from the Nanda Devi website. The other photos are ours.

Finally, we would like to acknowledge the full support and cooperation of the local people in the communities of the Niti Valley, without which this study would not have been completed. Their case is a case in point of the practical realities and effects of conservation on people, communities, and livelihoods, and the need to rethink some conservation actions and provide mitigating measures to address the social and economic dislocation they bring on marginal mountain communities. This publication is a tribute to their heroism and dedication and a statement of support for mitigating the effects of conservation. 


\section{executive summary}

This discussion paper is about a unique physical and cultural landscape nestled in the northern part of the western Himalayas. The paper attempts to present the inside story of the people who inhabit this area and the complex web of issues they are entangled in. Their struggle is decades old and so are their vows. They are the people who live in the buffer zone of the Nanda Devi Biosphere Reserve (NDBR), located in the State of Uttaranchal in India.

As in many other protected areas, this region has witnessed severe and prolonged protests by the local community. Recently the protests in the NDBR have attracted wide attention. A number of national and international agencies have been observing keenly the recent sequence of events in the region. This Talking Points volume is being presented at a crucial phase in this struggle. The recently formed State of Uttaranchal has issued an order for the partial opening of the core zone of Nanda Devi for regulated tourism activities along the lines of community-based tourism. Though the demand charter of the local community is comprehensive, the opening of the core zone has changed the entire scenario. Now for the first time there are concrete opportunities for the local community to rejuvenate its economy. However, there are several strings attached to this package of opportunities. Skills, responsibilities, sustainability, management, and equity are some of the keywords that the community has to now understand and learn to deal with. This will be more challenging than the struggle itself.

This report is based on fieldwork and a review of the relevant literature. It discusses the history of the local community and browses through some of the salient features of the area, and focuses on the crux of the problem and the ways to resolve it. This analysis, it is hoped, will facilitate the campaign for the sustainable development of the region and may help in the promulgation of similar campaigns elsewhere. 


\section{acronyms and abbreviations}

$\begin{array}{ll}\text { CPR } & \text { common property resource } \\ \text { IMF } & \text { Indian Mountaineering Foundation } \\ \text { IRs } & \text { Indian rupee } \\ \text { masl } & \text { metres above sea level } \\ \text { MLA } & \text { Member of Legislative Assembly } \\ \text { NDBR } & \text { Nanda Devi Biosphere Reserve } \\ \text { NDNP } & \text { Nanda Devi National Park } \\ \text { NTFP } & \text { non-timber forest product }\end{array}$




\begin{abstract}
baisakhi the harvest season, observed on the 13th of April each year
bari system rotational duty of a family to take the lead on collective issues. The patterns of operation vary from village to village, and villages improvise on details according to their needs or the requirements of existing conditions
\end{abstract}

basant panchami fifth day of spring in the lunar calendar

Bhotiya a tribal community, mostly living in the highlands (Bhotiya communities are dominant in the Niti Valley)

gram pradhan chairperson or head of the village common assembly

gram sabha meeting of the elected village council

guchhi mushroom (Morchella esculenta) belonging to the family Helvellaceae

jhapto cheeno take by force

kharif summer cropping season, usually during the rainy months from June to October

rabi winter cropping season, usually during the dry season from November to May

ringal thin cane used for making baskets, mats, and other household goods

Katyuri Katyuri was the first historical dynasty during the 11th century $A D$; it ruled over unified Uttarakhand and left important records in the form of inscriptions and temples. In later periods, after the downfall of Katyuri, it is believed that Garhwal region was fragmented into more than 64 principalities.

maanis unit of weight equivalent to two pounds

mahila mangal village women's groups

dals

Pandava protagonists of the Mahabharata's war - they are five virtuous brothers fighting the evil Kaurava in the war between good and evil 
pramukh headman

scheduled caste caste at the bottom of the social hierarchy and regarded as untouchable; the Indian Constitution allows the President to draw up the list of groups that constitute the scheduled castes; the government maintains these lists to protect and promote the interests of the scheduled castes.

Vanaadhikar 'Forest Rights' - an NGO in Uttaranchal advocating for people's rights over forest commons

van panchayat community-based forest management legalised by the Kumaon Van Panchayat Rule 1931 following grievances by communities over their loss of usufruct, their legal right to use and derive profit from the forest provided that the forest itself is not injured in any way.

yuvak mangal village youth groups

dals 
preface

acknowledgements

executive summary

acronyms and abbreviations

glossary

Introduction

Nanda Devi Biosphere Reserve Timeline 2

Land and People of the Niti Valley 5

Topography 5

Villages $\quad 5$

Livelihoods 6

$\begin{array}{ll}\text { Cultural heritage and rituals of the Bhotiyas } & 7\end{array}$

The indigenous management system $\quad 8$

The Chipko Movement and the Bhotiya Community 13

The Nanda Devi National Park $\quad 15$

Impact of Restrictions on the Local Communities $\quad 16$

Impact on livestock economy $\quad 17$

$\begin{array}{ll}\text { Impact on agriculture } & 18\end{array}$

$\begin{array}{ll}\text { Loss of the ethno-medicinal system } & 19\end{array}$

Cultural loss 21

Loss of income from tourism 21

$\begin{array}{ll}\text { Conservation Policy and Livelihoods } & 23\end{array}$

From Confrontation to Conflict Resolution 25

$\begin{array}{ll}\text { Miles to Go } & 29\end{array}$

$\begin{array}{ll}\text { Bibliography } & 30\end{array}$

Annex:

The Nanda Devi Biodiversity Conservation and Ecotourism Declaration 32 